\title{
Role of decomposition of mangrove and seagrass detritus in sediment carbon and nitrogen cycling in a tropical mangrove forest
}

\author{
Marianne Holmer*, Annemarie Bachmann Olsen
}

Institute of Biology, SDU-Odense University, Campusvej 55, 5230 Odense M, Denmark

\begin{abstract}
The elemental composition and in situ decomposition of detritus of Rhizophora apiculata and Enhalus acoroides were studied in mangrove and seagrass bed sediments in the Bangrong mangrove, Phuket, Thailand, and compared with controlled laboratory flux incubations. At the field site detritus was buried in litter-boxes in the sediments and changes in particulate organic carbon and nitrogen in detritus and sediments were followed for up to 2 mo. In the flux incubations the sediments were amended with mangrove and seagrass leaves and rhizomes, and the exchange of oxygen, $\mathrm{CO}_{2}$, dissolved organic carbon (DOC) and inorganic nitrogen was measured across the sediment-water interface for $43 \mathrm{~d}$. The decomposition of seagrass leaves was rapid both in situ and in the laboratory, whereas about $40 \%$ of the mangrove leaves remained after $43 \mathrm{~d}$, and no decomposition could be detected for the seagrass rhizome detritus. There was an immediate increase in sediment oxygen uptake (SOU) in the seagrass sediments followed by an increase in $\mathrm{CO}_{2}$ production after the addition of detritus, whereas the SOU remained low in the mangrove sediments. The C:N ratios decreased in the carbon-rich mangrove leaves and seagrass rhizome detritus, but increased in the less carbon-rich seagrass leaves during the decomposition. The decrease in C:N ratio was attributed to colonization by bacteria which incorporated nitrogen from the overlying water column or from the indigenous particulate organic nitrogen pool in the sediments. The mineralised carbon from the plant detritus was recovered as $\mathrm{CO}_{2}$, whereas no accumulation or release of DOC was found. The effect of amendment with mangrove detritus on the nitrogen fluxes was minor, whereas the uptake of nitrate and release of ammonium was enhanced with the seagrass leaves. About 32 to $36 \%$ of the mineralised nitrogen from the seagrass leaves was released across the sediment-water interface, where it became available for primary producers or exported to adjacent ecosystems
\end{abstract}

KEY WORDS: Mangrove $\cdot$ Seagrass $\cdot$ Nutrient cycling $\cdot$ Decomposition $\cdot$ Tropical sediments

\section{INTRODUCTION}

Mangroves are productive coastal forest areas, and their associated food chain and nutrient cycles are often closely linked to those in adjacent coastal waters (Alongi et al. 1993, Alongi 1996). The trees can be regarded as links between the terrestrial and marine ecosystems (Chale 1993), and mangrove ecosystems are open, with exchange of nutrients, detritus and sediment facilitated by tidal flushing (Woodroffe 1985, Lee 1995). The habitat receives nutrient and organic

*E-mail: holmer@biology.sdu.dk detritus through runoff from land and from freshwater streams (Morell \& Corredor 1993) and nutrients are effectively recycled within the ecosystem (RiveraMonroy et al. 1995, Holmer et al. 2001). The extent to which mangroves exchange dissolved and particulate nutrients with adjacent waters depends on several factors, including geomorphology, tidal regime and climate (Alongi 1996). Mangroves are considered to play an important role in controlling coastal hydrodynamics and sediment movements (Boto 1992, Eong 1993), but in general the chemical and biological links between mangroves and near-shore waters are poorly understood (Boto \& Wellington 1988, Hemminga et al. 1994). 
During the last decades, there have been a number of studies on the degradation of mangrove litter using litter-bags (Wafar et al. 1997, Ashton et al. 1999). These have shown rapid initial decomposition followed by low rates and accumulation of refractory compounds. The detritus is often enriched by nitrogen during decomposition (Wafar et al. 1997). The existing knowledge of decomposition of mangrove detritus in sediments is, however, sparse. Nitrogen fixation is generally low in mangrove sediments, diminishing the potential for nitrogen enrichment during decomposition (Kristensen et al. 1998), whereas the larger nutrient pools provide a potential for bacterial nitrogen incorporation directly from porewater pools (Kristensen et al. 1998, Holmer et al. 2001).

Seagrass beds have a high nutrient demand to support their high production, but a number of processes such as loss of detached leaves and leaf fragments leads to nutrient loss from these systems. The persistence of seagrass meadows is dependent on processes that counterbalance the nutrient loss, such as trapping of dissolved nutrients and particulate matter (Hemminga et al. 1991, Slim et al. 1996). In tropical areas, where nutrient concentrations in seawater typically are low, the nutrient demand of seagrasses appears to be met by efficient systems of nutrient trapping, uptake and recycling (Hemminga \& Nieuwenhuize 1991, Erftemeijer \& Middelburg 1995). Nutrient recycling can be accomplished through rapid in situ decomposition of seagrass-derived organic matter within the seagrass beds, although the rate of decomposition of detritus in these low-nutrient environments may be constrained by nutrient limitation as the decomposing plant tissues have lower nutrient contents than the decomposing bacteria (Fenchel et al. 1998).

Only a few studies have investigated the plant decomposition in tropical sediments and the effect of plant decomposition on carbon oxidation and the fluxes of nutrients between sediment and water (Enriquez et al. 1993). The aim of the present study was to obtain detailed knowledge on the factors that control organic carbon and nitrogen mineralisation during decomposition of mangrove tree Rhizophora apiculata and seagrass Enhalus acoroides material at the sediment surface and buried in the sediments in the mangrove and in the seagrass bed. Nitrogen cycling during decomposition was examined in order to quantify the amount of nutrients available for transport between the mangrove and the seagrass bed. A field experiment was designed to measure long-term decomposition of detritus ( $2 \mathrm{mo}$ ), and a parallel laboratory experiment was established to measure the flux of carbon and nitrogen across the sediment-water interface and changes in particulate and dissolved carbon and nitrogen pools in the sediment during decomposition.

\section{MATERIALS AND METHODS}

Study site and sampling. Sediment and detritus were collected from February to August 1999 in the Bangrong mangrove and in the seagrass bed in front of the mangrove at Phuket Island, Thailand ( $\left.8^{\circ} 03^{\prime} \mathrm{N}, 98^{\circ} 25^{\prime} \mathrm{E}\right)$. The average temperature was $28^{\circ} \mathrm{C}$ (Kristensen et al. 1995) and average salinity was $35 \%$ (Holmer et al. 1999). The tidal range was 1.1 to $3.7 \mathrm{~m}$ (Boonruang 1978, Poovachiranon \& Chansang 1994). Experiments were carried out at 2 stations, 1 situated inside the Bangrong mangrove (MB) and 1 in the seagrass bed (SB). At neap tide MB was submerged for $17 \mathrm{~h}$ and SB for $19 \mathrm{~h}$, while both stations were submerged for $24 \mathrm{~h}$ during spring tide. The sediment composition at $\mathrm{MB}$ was silty clay or silt. SB was located about $900 \mathrm{~m}$ outside the mangrove forest in a low-intertidal sandy sediment. The vegetation of Enhalus acoroides was about 50 plants $\mathrm{m}^{-2}$ distributed in patches of 2 to $4 \mathrm{~m}^{2}$.

Field litter-box experiment. Sediment was sampled by hand from the upper $10 \mathrm{~cm}$ at MB and SB and transported to the laboratory. Here the sediment was mechanically homogenised before use and initial samples were taken for wet weight (WW), dry weight (DW) and dissolved inorganic nitrogen (DIN) analysis. Yellow leaves of Rhizophora apiculata were collected from trees at $\mathrm{MB}$ to ensure that they were of similar age and without crab cuttings. The leaves were cut in half, weighed, and one-half buried in the sediment. The other half was kept for initial measurement of organic matter concentrations. Seagrass leaves and rhizomes were sampled at SB by collection and digging. They were rinsed in seawater to remove epiphytes and sediment, and excess water was wiped off carefully with a paper towel before the leaves were cut just above the leaf sheath in pieces of $14 \mathrm{~cm}$. Leaf samples were kept for initial values of DW and organic nitrogen (plant $\mathrm{N}$ ) and carbon (plant $\mathrm{C}$ ).

A total of 60 litter-boxes (dimension $5 \mathrm{~cm} \times 10 \mathrm{~cm} \times$ $14 \mathrm{~cm}$, mesh size of $2 \mathrm{~mm}$ ) were prepared with sediment and various plant materials. In the litter-boxes with Rhizophora apiculata the leaf pieces were placed $2 \mathrm{~cm}$ apart horizontally, and the leaves were completely covered with sediment. In the litter-boxes containing Enhalus acoroides, 6 leaves were placed in pairs, $1 \mathrm{~cm}$ vertically and $2 \mathrm{~cm}$ horizontally apart. For MB, 15 litter-boxes were filled with $R$. apiculata leaves and 15 with sediment only (control). For SB 15 litterboxes were filled with $R$. apiculata leaves, 15 with $E$. acoroides leaves and 15 with only sediment. The litterboxes were buried in the sediment at the field sites at $7 \mathrm{~cm}$ depth the day after preparation with about $2 \mathrm{~cm}$ between each litter-box and $2 \mathrm{~cm}$ of sediment on top of the litter-boxes. A min./max. thermometer was placed at the stations to obtain the temperature range 
between samplings. The litter-boxes were sampled after 1, 2, 4, 6 and 13 wk at MB and 1, 2, 4, 7 and 9 wk at SB. At each sampling, 6 to 9 litter-boxes were collected: 3 controls, 3 with E. acoroides leaves, and 3 with $R$. apiculata leaves. The plant material, if any, was collected, cleaned in distilled water, dried in a paper towel, weighed and dried at $60^{\circ} \mathrm{C}$ for $24 \mathrm{~h}$. The sediment in the litter-boxes was homogenized and sampled for dry weight and POC and PON content.

Flux experiments. Sediment flux cores (i.d. $8 \mathrm{~cm}$, length $25 \mathrm{~cm}, 3$ replicates) were established similar to the litter-boxes: control cores with sediment from $\mathrm{MB}$ or SB and with Rhizophora apiculata leaf material (3.0 to $3.2 \mathrm{~g} \mathrm{WW}$ ) were buried $2 \mathrm{~cm}$ in sediment from $\mathrm{MB}$ or $\mathrm{SB}$, and cores with Enhalus acoroides leaf material (3.7 to $4.1 \mathrm{~g} \mathrm{WW}$ ) buried in sediment from SB. Two additional treatments were established with seagrass detritus: cores with E. acoroides leaf material (4.0 to $4.5 \mathrm{~g}$ WW) were placed on top of sediment from SB, and cores with rhizomes (10.5 to $11.0 \mathrm{~g} \mathrm{WW}$ ) were buried in sediment from SB. The leaves were collected and treated as for the litter-boxes and cut in 5 to $7 \mathrm{~cm}$ pieces. Roots were removed from the rhizomes and rhizomes were cut in pieces of 5 to $7 \mathrm{~cm}$. All cores were kept submerged in an aerated incubator (200 l) in the dark at a temperature of 26 to $29^{\circ} \mathrm{C}$ and a salinity of 30 to $34 \%$. The water column in each core was mixed by a magnet driven by an external rotating magnet (50 rpm). The experiment lasted for $6 \mathrm{wk}$ with (bi-) weekly measurements of $\mathrm{O}_{2}, \mathrm{CO}_{2}$, dissolved organic carbon (DOC) and dissolved inorganic nitrogen (DIN) fluxes. The first incubation for $\mathrm{O}_{2}$ and $\mathrm{CO}_{2}$ fluxes lasted 2 to $4 \mathrm{~h}$. The cores were allowed to equilibrate for 8 to $10 \mathrm{~h}$ before an incubation of $16 \mathrm{~h}$ for DOC and DIN measurements was done. At the beginning of each incubation the water column in the cores was mixed carefully by bubbling with air, and initial samples were taken before the cores were sealed with a lid. At the end of the incubation, samples were taken through a hole in the lid. Oxygen and $\mathrm{CO}_{2}$ were analysed within $10 \mathrm{~h}$, whereas samples for DOC and DIN were frozen and analysed later.

The sediment cores were sectioned after $6 \mathrm{wk}$ to obtain pore water and sediment characteristics at the following intervals: $0-1,1-3,3-5$ and $5-8 \mathrm{~cm}$. Porewaters were obtained by centrifugation in single tubes from $\mathrm{MB}$ and in double centrifuging tubes from SB (3000 rpm, $10 \mathrm{~min}$ ). The pore water was sampled for DOC and DIN and the sediment for POC and PON. The plant material-if any-was removed carefully, washed gently in distilled water before being dried at $60^{\circ} \mathrm{C}$ for $24 \mathrm{~h}$ and stored for later analysis of plant $\mathrm{C}$ and $\mathrm{N}$.

Analysis. Sediment, plants and water were analysed as follows.
Sediment and plant characteristics: Organic carbon and nitrogen in the sediment and plant material were obtained by elemental analysis on a Carlo-Erba 1100 EA CHN-analyzer according to the method of Kristensen \& Andersen (1987).

Water analysis: Oxygen was determined by manual Winkler titrations. $\mathrm{CO}_{2}$ was measured by flowinjection analysis according to Hall \& Aller (1992). Dissolved organic carbon was analysed by high-temperature combustion on a Shimadzu TOC-5000 (Sharp 1997). Nitrite $\left(\mathrm{NO}_{2}^{-}\right)$and nitrate $\left(\mathrm{NO}_{3}^{-}\right)$were measured through the standard autoanalyser method by flow injection (Tecator FIA star 5012: Armstrong et al. 1967). Nitrite concentrations were low and are included in the $\mathrm{NO}_{3}{ }^{-}$pools. Ammonium $\left(\mathrm{NH}_{4}{ }^{+}\right)$was measured according to the method of Bower \& Holm-Hansen (1980).

Statistical analysis. Student's $t$-tests and a 1-way analysis of variance (ANOVA) were used to test for differences in decomposition of detritus related to sediment type and species and to test for effects of detritus on sediment metabolism and nutrient fluxes. Probabilities (p) of $<0.05$ were considered to be significant. Homogeneity of variance was ensured before ANOVA tests were made.

\section{RESULTS}

There was no significant difference in the loss of dry weight of Rhizophora apiculata in the 2 sediments at the field site (Fig. 1). During the incubation of 43 to $64 \mathrm{~d}$ about $50 \%$ of the plant material was decomposed. There was a minor increase in weight during the first $8 \mathrm{~d}$, but it declined to $60 \%$ of the initial weight within the first $8 \mathrm{~d}$, and was followed by low rates of decay. The decomposition was modelled with a single exponential model, and the decay constant $(k)$ was estimated to 0.0075 and $0.013 \mathrm{~d}^{-1}$ in mangrove and seagrass sediments, respectively. The changes in plant $\mathrm{C}$ and $\mathrm{N}$ content in the leaf material were minor (data not shown). The plant $\mathrm{C}$ content of mangrove leaves increased in the mangrove sediments after $2 \mathrm{wk}$ incubation, but decreased to initial level after 2 mo. In the seagrass sediment the plant $\mathrm{C}$ content decreased by $12 \%$. The plant $\mathrm{N}$ in contrast increased and was 15 to $44 \%$ higher at the end of the experiment. These changes were reflected in the C:N ratios (Fig. 1), which increased to $>100$, and were followed by an almost linear decrease in both sediments to about 70 after 43 to $64 \mathrm{~d}$. The sediment organic matter content was measured several times during the experiment, and there were no significant differences with time (ANOVA, $\mathrm{p}>0.05)$. The mangrove sediment had a POC content of 4.0 to $4.1 \% \mathrm{DW}$, a PON content of 0.24 to $0.25 \% \mathrm{DW}$, and a C:N ratio of 18.3 to 19.3. In the seagrass 

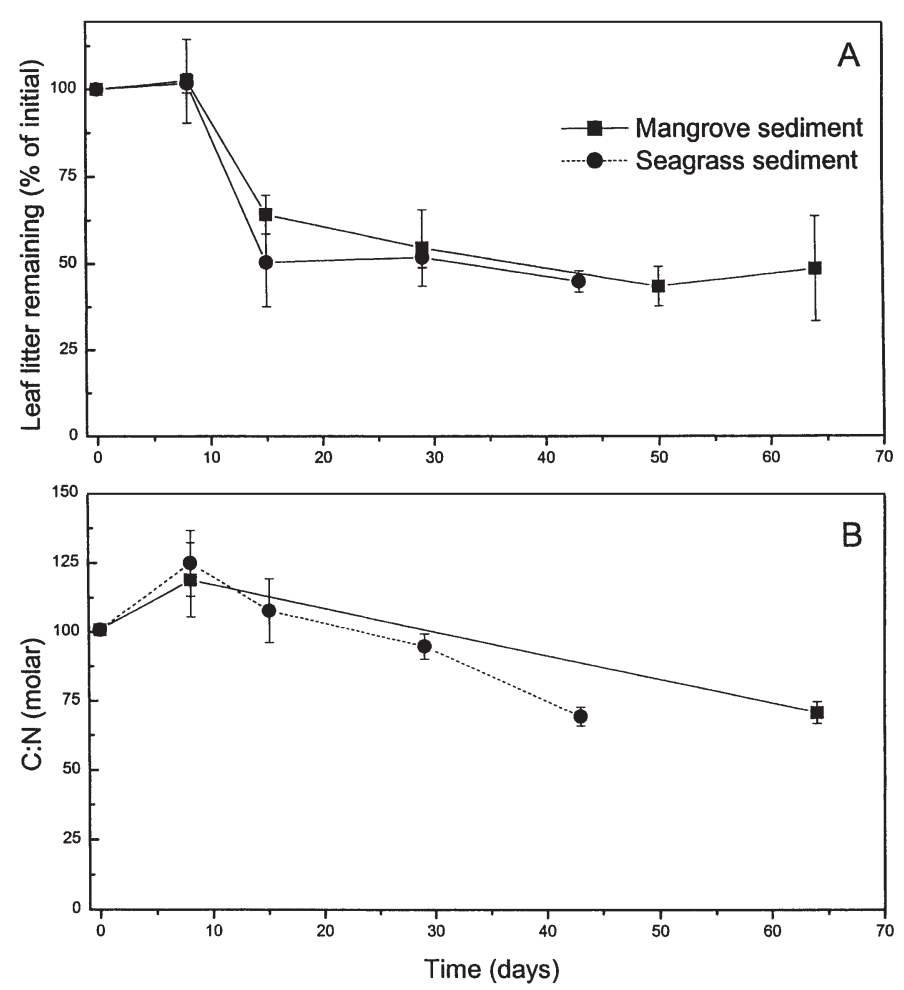

Fig. 1. Rhizophora apiculata. Litter-box experiment with leaf litter in mangrove and seagrass sediments. (A) Time-dependent changes in leaf litter remaining (as percentage of the amount added); (B) time-dependent changes in the molar $\mathrm{C}: \mathrm{N}$ ratio in the leaf litter. Values are means $( \pm \mathrm{SE}, \mathrm{n}=4)$

sediments the parameters were: POC 0.25 to $0.27 \%$ DW, PON 0.007 to $0.010 \%$ DW, and C:N 32.0 to 40.0 .

There was a larger difference in decomposition between sediment types in the laboratory experiment, and the weight loss after $42 \mathrm{~d}$ was significantly higher $(\mathrm{p}=0.03)$, with $41.8 \pm 4.8 \%$ compared to $31.2 \pm 2.8 \%$ in the mangrove and seagrass sediment, respectively. The plant $\mathrm{C}$ and $\mathrm{N}$ content increased in both sediments (Table 1), but the increase was largest for plant $\mathrm{N}$ and the $\mathrm{C}: \mathrm{N}$ ratios decreased from 86.4 to 56.6 and 53.7 in the mangrove and seagrass sediment, respectively.

The deposition of leaf material increased the sediment oxygen uptake (SOU) only in the seagrass sediments (Fig. 2). The SOU increased to a maximum after $15 \mathrm{~d}$ incubation, and decreased towards the end of the experiment, when there was no significant difference between amended and control sediments $(\mathrm{p}>0.05)$. The $\mathrm{CO}_{2}$ production was up to 3 times greater in the amended sediments with maximum stimulation in the seagrass sediment. The maximum was obtained after 1 wk of incubation, followed by decreasing rates. The flux of DOC was low $\left(<0.5 \mathrm{mmol} \mathrm{m}^{-2} \mathrm{~d}^{-1}\right)$ compared to the $\mathrm{CO}_{2}$ production, and the direction of the fluxes changed between uptake and efflux.

The time-integrated oxygen flux was maximum in the seagrass sediment, where it was $72 \%$ higher than the control flux (Table 2). A similar pattern was found for the $\mathrm{CO}_{2}$ production, which was $103 \%$ higher than the control sediments. In the mangrove sediment the $\mathrm{CO}_{2}$ production was $97 \%$ higher than the control. The production of $\mathrm{CO}_{2}$ corresponded to 46 and $55 \%$ of the loss of carbon from the leaf materials in the mangrove and seagrass sediment, respectively (Table 2). There was a small net uptake of DOC $\left(\sim 0.1 \%\right.$ of $\mathrm{CO}_{2}$ production) in all sediments, except for the control seagrass sediments where there was a similar small net release.

The flux of nitrate was generally low in both sediments, and was primarily directed out of the sediment (Fig. 3). There was an effect of addition of leaf material in the seagrass sediments, where the amended sediments showed a lower efflux which increased with time to the control level. There was a variation with time, independent of the amendment in the mangrove sediments, whereby nitrate was released during most of the time, except for an initial uptake and an uptake after $30 \mathrm{~d}$ of incubation. The fluxes of ammonium were higher, and ammonium was taken up initially with decreasing rates over time in the mangrove sediments, whereas there was a small release initially in the seagrass sediments amended with leaf material.

The time-integrated fluxes of nitrate were lowest in the sediments amended with leaf material, and the flux of nitrate was generally 3 to 4 orders of magnitude lower than the ammonium fluxes (Table 3). There was a net uptake of ammonium, which was maximum in the control

Table 1. Rizophora apiculata and Enhalus acoroides. Elemental composition of plants (\% DW) and molar C:N ratios in laboratory experiment at initiation (Initial) and after $43 \mathrm{~d}$ decomposition (End). Initial values are mean of 3 replicate samples, and end values represent 1 measurement of homogenised plant material from 3 sediment cores

\begin{tabular}{|c|c|c|c|c|c|c|}
\hline \multirow[t]{2}{*}{ Species } & \multicolumn{2}{|c|}{$\begin{array}{l}\text { Plant C } \\
\text { (\% DW) }\end{array}$} & \multicolumn{2}{|c|}{$\begin{array}{l}\text { Plant N } \\
\text { (\% DW) }\end{array}$} & \multicolumn{2}{|c|}{$\begin{array}{c}\mathrm{C}: \mathrm{N} \\
\text { (molar) }\end{array}$} \\
\hline & Initial & End & Initial & End & Initial & End \\
\hline \multicolumn{7}{|l|}{$R$. apiculata } \\
\hline Mangrove sediment & 34.81 & 47.20 & 0.47 & 0.97 & 86.4 & 56.6 \\
\hline Seagrass sediment & 34.81 & 39.92 & 0.47 & 0.87 & 86.4 & 53.7 \\
\hline \multicolumn{7}{|l|}{ E. acoroides } \\
\hline Leaves surface & 34.88 & 21.88 & 3.28 & 0.85 & 12.4 & 30.1 \\
\hline Leaves buried & 34.88 & 38.12 & 3.28 & 2.66 & 12.4 & 16.7 \\
\hline \multicolumn{7}{|l|}{ E. acoroides } \\
\hline Rhizomes & 28.97 & 30.24 & 0.37 & 0.73 & 71.8 & 48.6 \\
\hline
\end{tabular}


Fig. 2. Rhizophora apiculata. Flux incubations with leaf litter in mangrove and seagrass sediments. Time-dependent changes in sediment oxygen uptake (SOU) for control and litteramended sediments in mangrove (A) and seagrass (B) sediments, for $\mathrm{CO}_{2}$ production $(\mathrm{C}, \mathrm{D})$ and for DOC fluxes $(\mathrm{E}, \mathrm{F})$. Values are means $( \pm \mathrm{SE}, \mathrm{n}=3)$
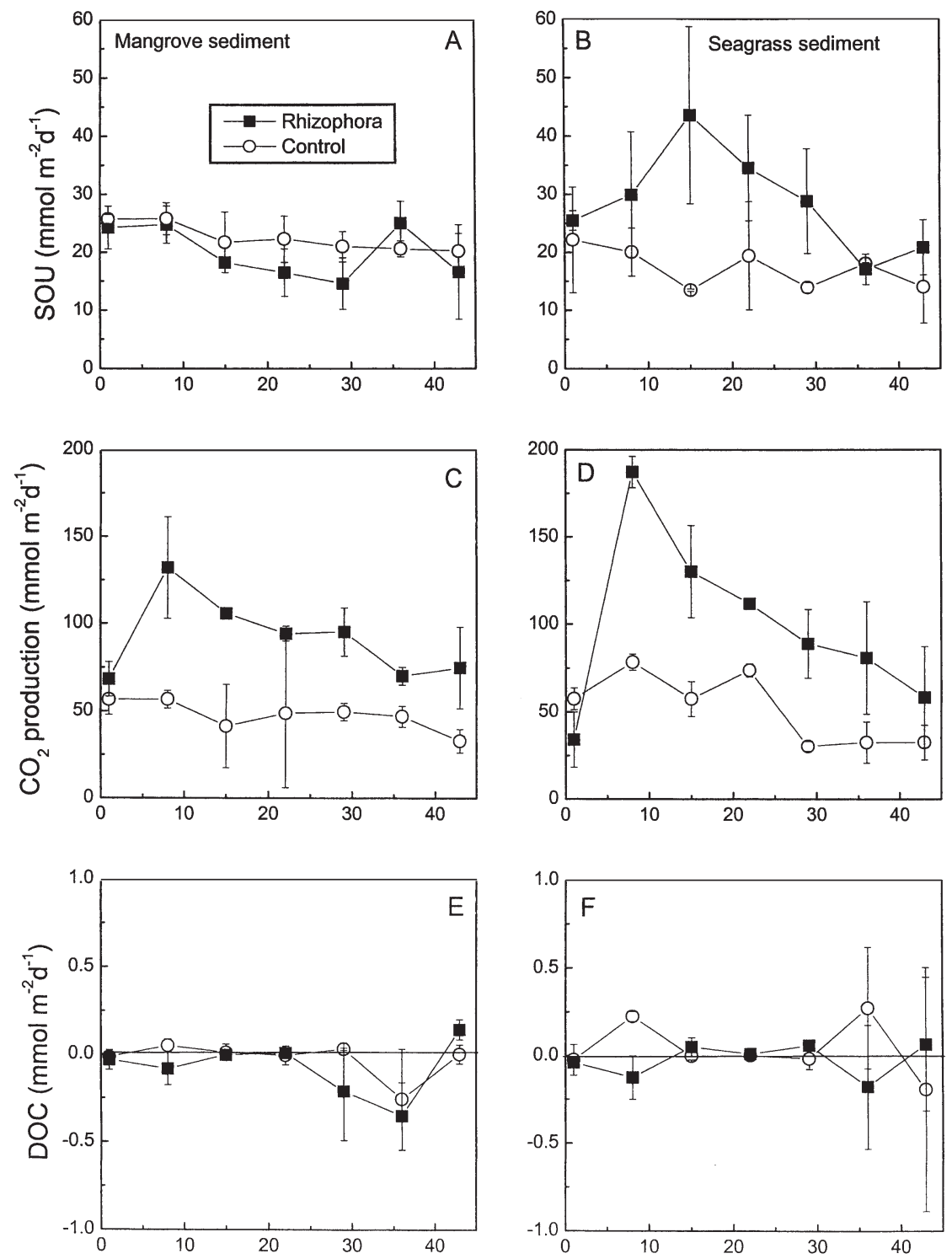

Table 2. Rizophora apiculata and Enhalus acoroides. Pool of added POC (Amendment) and time-integrated changes in plant carbon (Loss of plant C) and SOU, and $\mathrm{CO}_{2}$ and DOC fluxes during $43 \mathrm{~d}$ incubation (derived from Figs. 2, 5 \& 6).

Negative values for DOC fluxes represent uptake by the sediments

\begin{tabular}{|lccccr|}
\hline & $\begin{array}{c}\text { Amend- } \\
\text { ment }\end{array}$ & $\begin{array}{c}\text { Loss of } \\
\text { plant C }\end{array}$ & $\begin{array}{c}\text { Oxygen } \\
\text { consumption } \\
\left(\mathrm{mmol} \mathrm{C} \mathrm{m}^{-2}\right)\end{array}$ & $\begin{array}{c}\mathrm{CO}_{2} \\
\text { production }\end{array}$ & $\begin{array}{c}\text { DOC } \\
\text { flux }\end{array}$ \\
\cline { 2 - 6 } & \multicolumn{5}{c}{} \\
\hline Mangrove sediment & - & - & 837 & 2018 & -1 \\
$\quad$ Control & 7101 & 4260 & 941 & 3982 & -4 \\
R. apiculata & & & & & \\
Seagrass sediment & - & - & 720 & 2223 & 3 \\
Control (R. apiculata) & 7131 & 4168 & 1238 & 4516 & -1 \\
R. apiculata & - & - & 350 & 1850 & -64 \\
Control (E. acoroides) & 3555 & 2830 & 954 & 5175 & -22 \\
Surface & 3318 & 2984 & 625 & 4098 & -52 \\
Buried & 16524 & -646 & 740 & 4374 & -67 \\
Rhizome & & & &
\end{tabular}

sediments in the mangrove. The uptake of ammonium was quite similar in the amended sediments, and was of the same order of magnitude as the loss of nitrogen from the decomposing plant material (Table 3).

The porewater pools of nitrate were low, especially in the seagrass sediments, where the concentration was $<2 \mu \mathrm{M}$ (Fig. 4). The addition of leaf material decreased the pools even further. The ammonium concentration was highest in the seagrass sediment and increased with increasing depth up to $23 \mu \mathrm{M}$. The addition of leaf material increased the concentration of ammonium, but only in the seagrass 

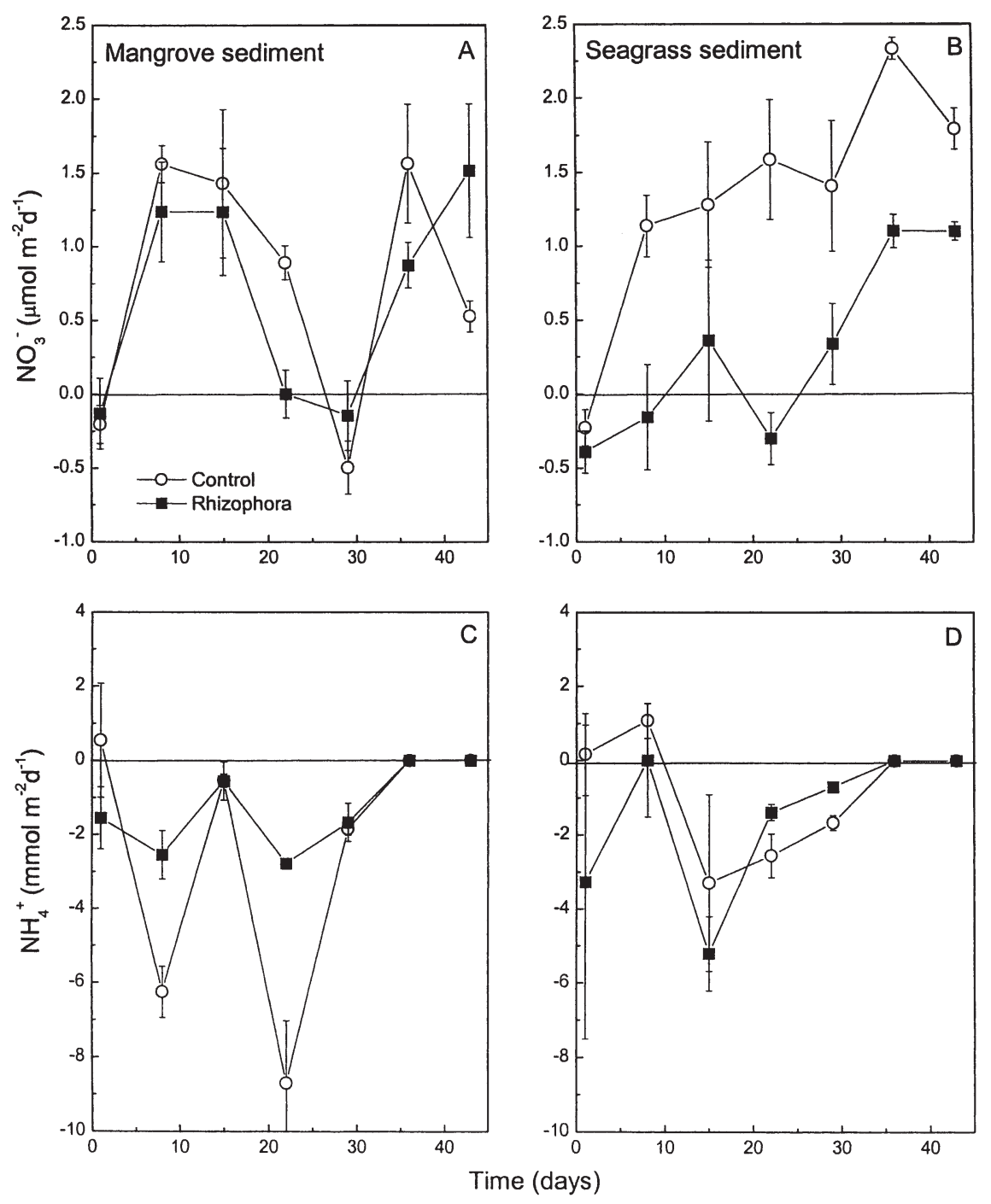

Fig. 3. Rhizophora apiculata. Flux incubations with leaf litter in mangrove and seagrass sediments. Time-dependent changes in nitrate fluxes $\left(\mathrm{NO}_{3}{ }^{-}\right)$for control and litteramended sediments in mangrove (A) and seagrass (B) sediments and for ammonium fluxes $\left(\mathrm{NH}_{4}^{+}\right)(\mathrm{C}, \mathrm{D})$. Values are means $( \pm \mathrm{SE}, \mathrm{n}=3$ )

Table 3 Rizophora apiculata and Enhalus acoroides. Pool of added plant organic nitrogen (Amendment) and time-integrated changes in plant nitrogen (Loss of plant $\mathrm{N}$ ) and fluxes of ammonium $\left(\mathrm{NH}_{4}\right.$ release) and nitrate $\left(\mathrm{NO}_{3}\right.$ release derived from Figs. 3 \& 7$)$. Final porewater pools of ammonium and nitrate are given (derived from Figs 4 \& 8). Negative values for ammonium and nitrate fluxes represent uptake by the sediments

\begin{tabular}{|c|c|c|c|c|c|c|}
\hline & $\begin{array}{c}\text { Amend- } \\
\text { ment } \\
\left(\mathrm{mmol} \mathrm{N} \mathrm{m}^{-2}\right)\end{array}$ & $\begin{array}{c}\text { Loss of } \\
\text { plant } \mathrm{N} \\
\left(\mathrm{mmol} \mathrm{N} \mathrm{m}^{-2}\right)\end{array}$ & $\begin{array}{c}\mathrm{NH}_{4} \\
\text { release } \\
\left(\mathrm{mmol} \mathrm{N} \mathrm{m}^{-2}\right)\end{array}$ & $\begin{array}{c}\mathrm{NO}_{3} \\
\text { release } \\
\left.(\mathrm{mmol} \mathrm{N} \mathrm{m})^{-2}\right)\end{array}$ & $\begin{array}{c}\mathrm{NH}_{4} \text { pore- } \\
\text { water final } \\
\left(\mathrm{mmol} \mathrm{N} \mathrm{m}{ }^{-2}\right)\end{array}$ & $\begin{array}{c}\mathrm{NO}_{3} \text { pore- } \\
\text { water final } \\
\left(\mathrm{mmol} \mathrm{N} \mathrm{m}^{-2}\right)\end{array}$ \\
\hline \multicolumn{7}{|l|}{ Mangrove sediment } \\
\hline Control & - & - & -120 & 0.036 & 0.30 & 0.163 \\
\hline R. apiculata & 121 & 71 & -58 & 0.027 & 0.24 & 0.067 \\
\hline \multicolumn{7}{|l|}{ Seagrass sediment } \\
\hline Control (R. apiculata) & - & - & -45 & 0.060 & 0.36 & 0.042 \\
\hline R. apiculata & 121 & 66 & -63 & 0.012 & 0.62 & 0.027 \\
\hline Control (E. acoroides) & - & - & 28 & 0.088 & 2.10 & 0.012 \\
\hline Surface & 287 & 262 & 112 & 0.006 & 1.54 & 0.022 \\
\hline Buried & 267 & 247 & 118 & 0.018 & 3.58 & 0.003 \\
\hline Rhizome & 183 & -170 & 117 & -0.010 & 2.94 & 0.002 \\
\hline
\end{tabular}




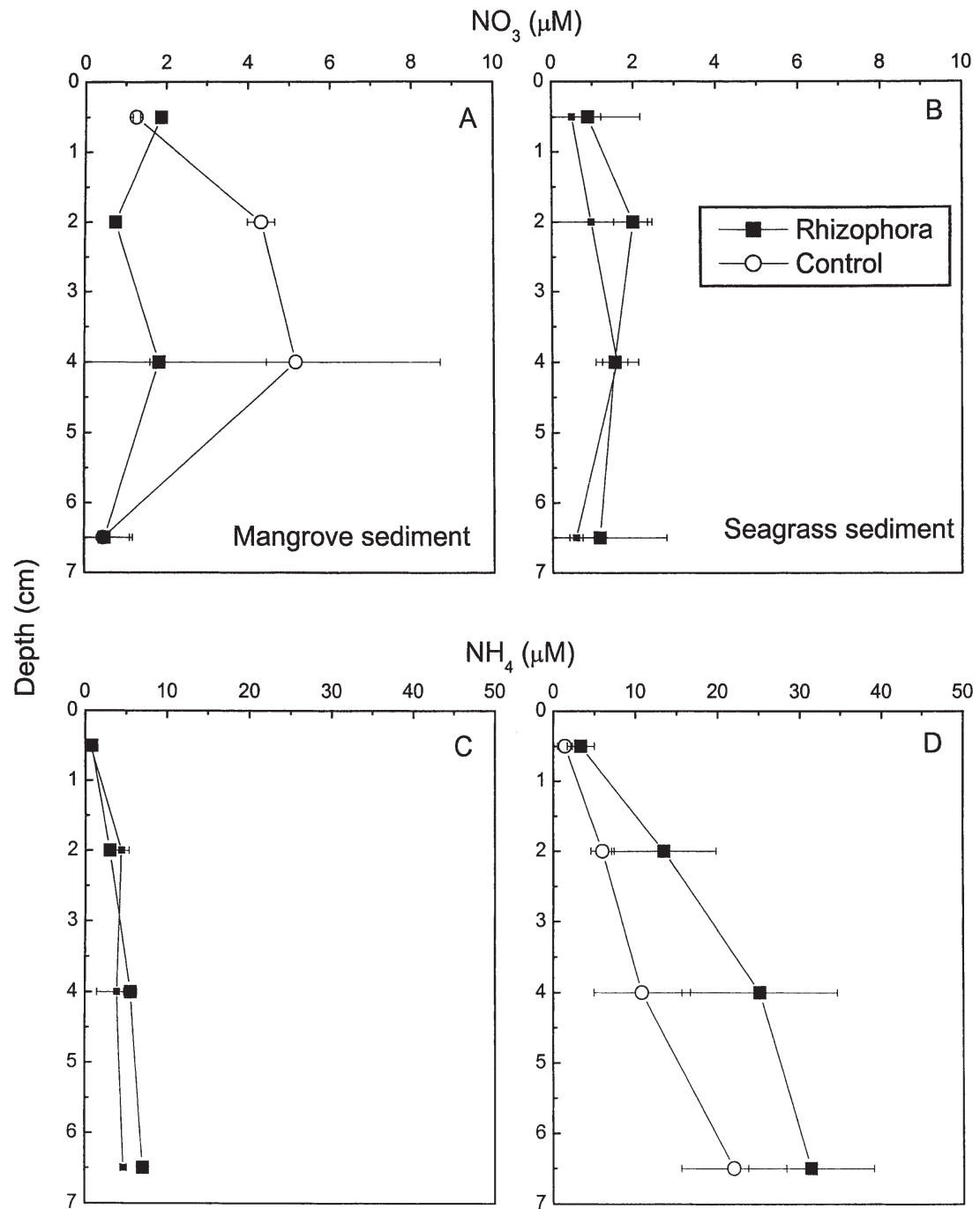

Fig. 4. Rhizophora apiculata. Porewater profiles obtained after $43 \mathrm{~d}$ incubation with leaf litter in mangrove and seagrass sediments. Nitrate concentrations in control and litter-amended mangrove (A) and seagrass (B) sediments, and ammonium concentrations in control and litter-amended mangrove $(\mathrm{C})$ and seagrass (D) sediments. Values are means $( \pm \mathrm{SE}, \mathrm{n}=3)$

sediment. The pools were between 27 and $623 \mu \mathrm{mol}$ $\mathrm{m}^{-2}$ (Table 3 ), which is $<0.1 \%$ of the sedimentary pools of PON.

The seagrass material was rapidly decomposed in the field, and it was not possible to find intact leaf material at the first sampling after $1 \mathrm{wk}$. In the laboratory experiment, $54.4 \pm 17.9 \%$ of the material was lost in the surface deposition, while $80.3 \pm 4.2 \%$ was lost from the buried leaves during the $43 \mathrm{~d}$ of decomposition. It was not possible to detect a loss of weight in the rhizome material. The plant $\mathrm{C}$ and $\mathrm{N}$ content decreased in the leaves on the sediment surface, while the plant $\mathrm{C}$ content increased in the leaves buried in the sediment (Table 1). Both plant $\mathrm{C}$ and $\mathrm{N}$ increased in rhizomes buried in the sediment (Table 1). The C:N ratio increased in the leaf materials from 12.4 to 30.1 and 16.7 for the surface and buried leaves, respectively (Table 1). The initial C:N ratios in the rhizomes was 71.8, decreasing to 48.6. There were no significant changes in POC and PON pools in the sediments during the experiment (data not shown).

The addition of seagrass material did in all cases increase the sediment oxygen uptake (Fig. 5). The largest stimulation was found for seagrass leaves deposited on the sediment surface. Initial SOU was high in all treatments and decreased to $<20 \mathrm{mmol} \mathrm{m}^{-2} \mathrm{~d}^{-1}$ with time. $\mathrm{CO}_{2}$ production was also affected by the amendments, with the largest stimulation being for seagrass leaves deposited on the sediment surface (Fig. 5). $\mathrm{CO}_{2}$ production was low during the first week, and increased to a maximum after $12 \mathrm{~d}$ (>150 mmol m $\mathrm{m}^{-2} \mathrm{~d}^{-1}$ ), subsequently decreasing to 50 to $70 \mathrm{mmol} \mathrm{m} \mathrm{m}^{-2} \mathrm{~d}^{-1}$. There was a small release of DOC from all the sediments initially, which changed to an uptake with time (Fig. 6).

The time-integrated SOU was up to 3 times higher in the amended sediments (Table 2). A similar stimulation was found for $\mathrm{CO}_{2}$ production. $\mathrm{CO}_{2}$ production was similar to or higher than the measured loss of plant carbon (Table 2). There was a net uptake of DOC of $~ 1 \%$ of the $\mathrm{CO}_{2}$ production (Table 2).

The addition of plant materials had a variable effect on the flux of nitrate (Fig. 7), which was low initially in the control and amended sediments and increased to a constant efflux. In sediments with leaves on the surface, an initial uptake was measured which increased until Day 15 (4 $\left.\mu \mathrm{mol} \mathrm{m} \mathrm{m}^{-2} \mathrm{~d}^{-1}\right)$, and was then followed by a release during the remaining period $\left(2 \mu \mathrm{mol} \mathrm{m} \mathrm{m}^{-2} \mathrm{~d}^{-1}\right)$. A similar pattern was found for the buried leaves, but with a lower uptake. For the rhizome material a low uptake was measured until Day 8 and again between Days 20 and 30, while there was a small efflux over the rest of the period $\left(1 \mu \mathrm{mol} \mathrm{m} \mathrm{m}^{-2} \mathrm{~d}^{-1}\right)$. The ammonium flux was 1 order of magnitude higher, and was released from the sediments with the highest rates from those amended with the leaf material (up to $9 \mathrm{mmol} \mathrm{m}^{-2} \mathrm{~d}^{-1}$; Fig. 7). The ammonium flux decreased with time in the control and the leaf-amended sediments to a low efflux $\left(<1 \mathrm{mmol} \mathrm{m}^{-2}\right.$ $\mathrm{d}^{-1}$ ), while 2 periods were observed for the rhizome material, each with a maximum efflux of about $4 \mathrm{mmol}$ $\mathrm{m}^{-2} \mathrm{~d}^{-1}$, during Days 5 to 8 and 22 to 30, respectively. 
The time-integrated fluxes of nitrate were insignificant compared to those of ammonium (Table 3). The efflux of ammonium was quite similar for the 3 amendments, about 3 times higher than in the control sediments. The ammonium efflux was $<50 \%$ of the nitrogen loss from the leaves (Table 3).

The porewater pools of nitrate were low $(<2 \mu \mathrm{M})$ and the amendments decreased the pools further (Fig. 8). The ammonium concentration was higher and increased with increasing depth (up to $250 \mu \mathrm{M}$ ). There was no effect on ammonium concentration by addition of leaves to the surface, whereas it increased in the sediment with buried seagrass material. The porewater pools were $<0.1 \%$ of sedimentary nitrogen pools and of the time-integrated nitrogen flux (Table 3).

\section{DISCUSSION}

\section{Decomposition rates of Rhizophora apiculata and Enhalus acoroides detritus}

The decay pattern of Rhizophora apiculata leaves in the field showed rapid early losses in biomass followed by a slower decrease for the remainder of the experiment. A single exponential model was used to describe the decomposition process. The decomposition constants were generally low compared to those in other studies (Wafar et al. 1997, Ashton et al. 1999, de Boer 2000); however, in most studies litter-bags have been placed on the sediment surface, which may enhance decomposition (Ashton et al. 1999, Dick \& Osunkoya 2000). Water-soaking causes leaching of labile materials and promotes leafconditioning by microbes (Chale 1993). The variation in rates of decomposition between the 2 sediment types may be due to differences in biogeochemical conditions. The mangrove sediment was compact, but also more organic and nutrient-rich than the seagrass sediment, suggesting that the potential for degradation was high in this sediment (Fenchel et al. 1998). The fastest decomposition was, however, found in the sandy, nutrient-poor seagrass sediments. It is likely that advective processes in the sandy seagrass sediments at the field site contribute to a higher $k$ value than in the mangrove sediments. The advection may reduce accumulation of toxic compounds such as tannins and increase the oxidation of the sediments, and thus enhance decomposition (Kristensen et al. 1995).

The decomposition of seagrass leaves was much faster than of the mangrove leaves, and it was not possible to recover intact plant materials from the field site after $1 \mathrm{wk}$ of decomposition. More leaf material (20 to $46 \%$ ) was recovered after $43 \mathrm{~d}$ in the laboratory experiment. The amount of seagrass leaves added to the sediment cores was almost twice as high as at the field site, and was deposited in 1 layer. At the field site, leaves were placed separately in the litter-boxes, which increased the contact area between sediment and detritus and most probably increased the rates of
Fig. 5. Enhalus acoroides. SOU and $\mathrm{CO}_{2}$ production in flux incubations with leaf and rhizome litter for control (A), leaf litter deposited on the surface (B), rhizome litter buried (C), and leaf litter buried in the sediments (D). Values represent mean $( \pm \mathrm{SE}, \mathrm{n}=3) \cdot \mathrm{CO}_{2}$ production measured at Day 29 is considered an outlier 


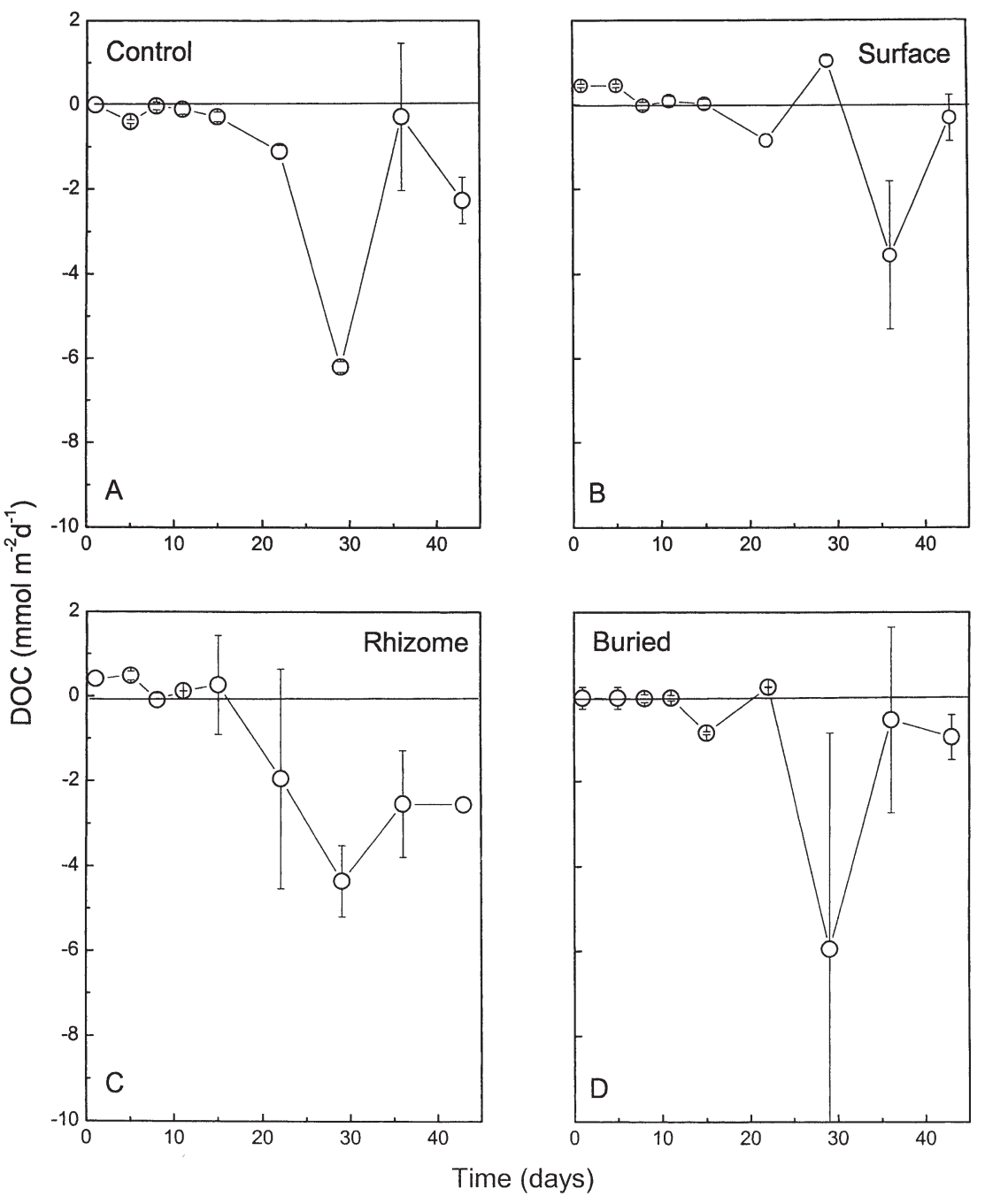

Fig. 6. Enhalus acoroides. Flux of DOC in incubations with leaf and rhizome litter for control (A), leaf litter deposited on the surface (B), rhizome litter buried $(\mathrm{C})$, and leaf litter buried in the sediments (D). Values are means $( \pm$ SEM, $\mathrm{n}=3)$ apiculata leaves, the initial nitrogen content of Enhalus acoroides leaves was almost 7 times higher, and thus potentially a better nutrient source for microorganisms (Enriquez et al. 1993, Fenchel et al. 1998). Also, the content of structural components of the seagrass is lower, and Benner \& Hodson (1985) found that lignocelluloses derived from mangrove leaves and wood were more resistant to microbial degradation than lignocelluloses from other marine macrophytes. The surface to volume area is much higher for the thin seagrass leaves than the thick mangrove leaves and rhizomes (Subramaniyan et al. 1984). Moran \& Hodson (1989) found that surface area is important in controlling the rate of bacterial decomposition. A higher abundance of bacteria in the sediments may thus account for the difference between decomposition of surface and buried seagrass leaves. Decomposition of E. acoroides rhizomes was much slower, and it was not possible to detect a loss of weight. Kenworthy \& Thayer (1984) measured a 50 to $60 \%$ loss of organic matter from roots and rhizomes of Zostera marina during a 170 d period, whereas the loss was $<10 \%$ in Thalassia testudium rhizomes in $247 \mathrm{~d}$. This suggests that the decomposition of seagrass rhizomes is quite variable, and is probably controlled by a number of factors, e.g. temperature, nutrient availability and sediment conditions. decomposition. Because of the lack of recovery of intact plant material at the field site, it was not possible to estimate a first-order decay constant, but the loss of seagrass leaves must have been at least $20 \% \mathrm{~d}^{-1}$. Seagrasses have been found to decompose relatively fast in temperate systems, approximately 20 to $50 \% \mathrm{mo}^{-1}$ (Newell et al. 1984, Harrison 1989, Peduzzi \& Herndl 1991, Pedersen et al. 1999), which is much lower than the rates encountered for Enhalus acoroides, suggesting that the decomposition of seagrass detritus is very fast in tropical waters.

There was a faster decomposition of seagrass leaves buried in the sediments compared to the surface deposition. This is in contrast to the findings for the mangrove leaves, where the decomposition was slower for buried leaves. Compared to Rhizophora

\section{Carbon dynamics during decomposition}

The burial of mangrove and seagrass detritus increased the SOU significantly for more than 1 mo in the seagrass sediments, whereas there was no significant difference in the mangrove sediments. The doubling of SOU in the seagrass sediments was not high compared to similar studies in temperate sediments with seagrass material (e.g. Zostera marina, for which rates were enhanced by up to 4 times by a similar organic matter addition; Pedersen et al. 1999), despite the fact that more seagrass detritus was decomposed in the tropical sediments. The mineralization of detritus buried in the sediments probably involved sulfate reduction and iron reduction, as these are the most important mineralization processes in the Bangrong 
mangrove (Holmer et al. 1999, Kristensen et al. 2000). Reduced compounds may accumulate in the sediments during iron and sulfate reduction, which decrease the immediate oxygen consumption but generate an oxygen deficiency in the sediments (Moeslund et al. 1994).
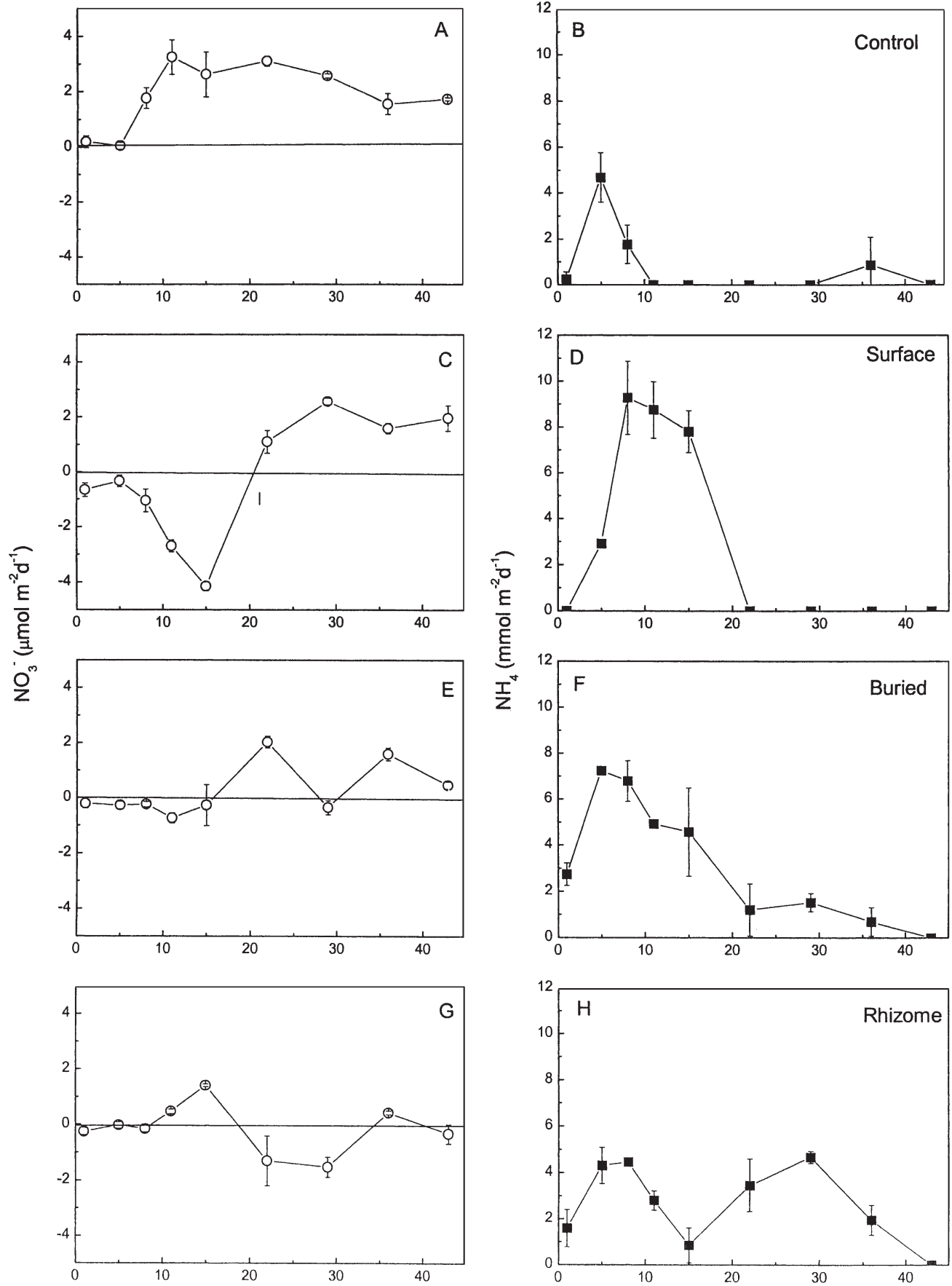

The loss of plant carbon in the flux incubations was generally higher than the amount of carbon recovered in the flux and pools of porewater and sediments, except for seagrass leaves deposited on the surface sediment and for rhizome material (Fig. 9A). The deficit in recovery of carbon may be due to a number of factors:
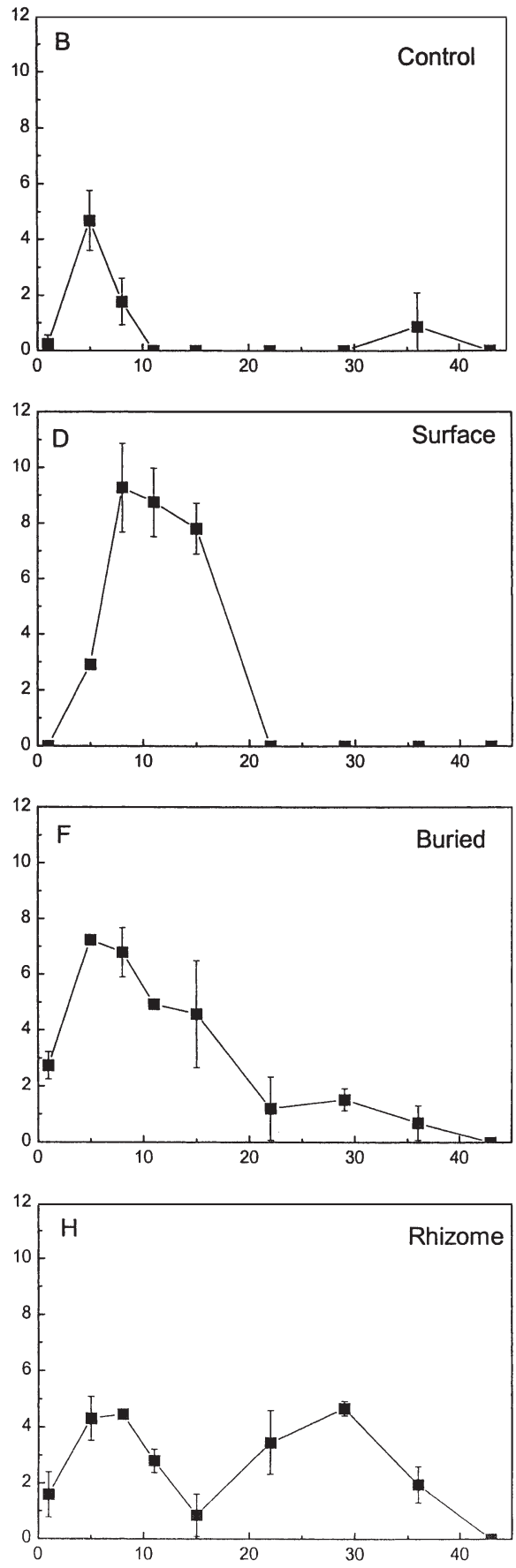

Fig. 7. Enhalus acoroides. Flux of nitrogen in incubations with leaf and rhizome litter. Nitrate (A) and ammonium (B) fluxes in control sediments, nitrate (C) and ammonium (D) fluxes in sediments with leaf litter deposited on the surface, and for leaf litter $(\mathrm{E}, \mathrm{F})$ and rhizome litter $(\mathrm{G}, \mathrm{H})$ buried in the sediments. Values are means $( \pm \mathrm{SE}, \mathrm{n}=3)$ 


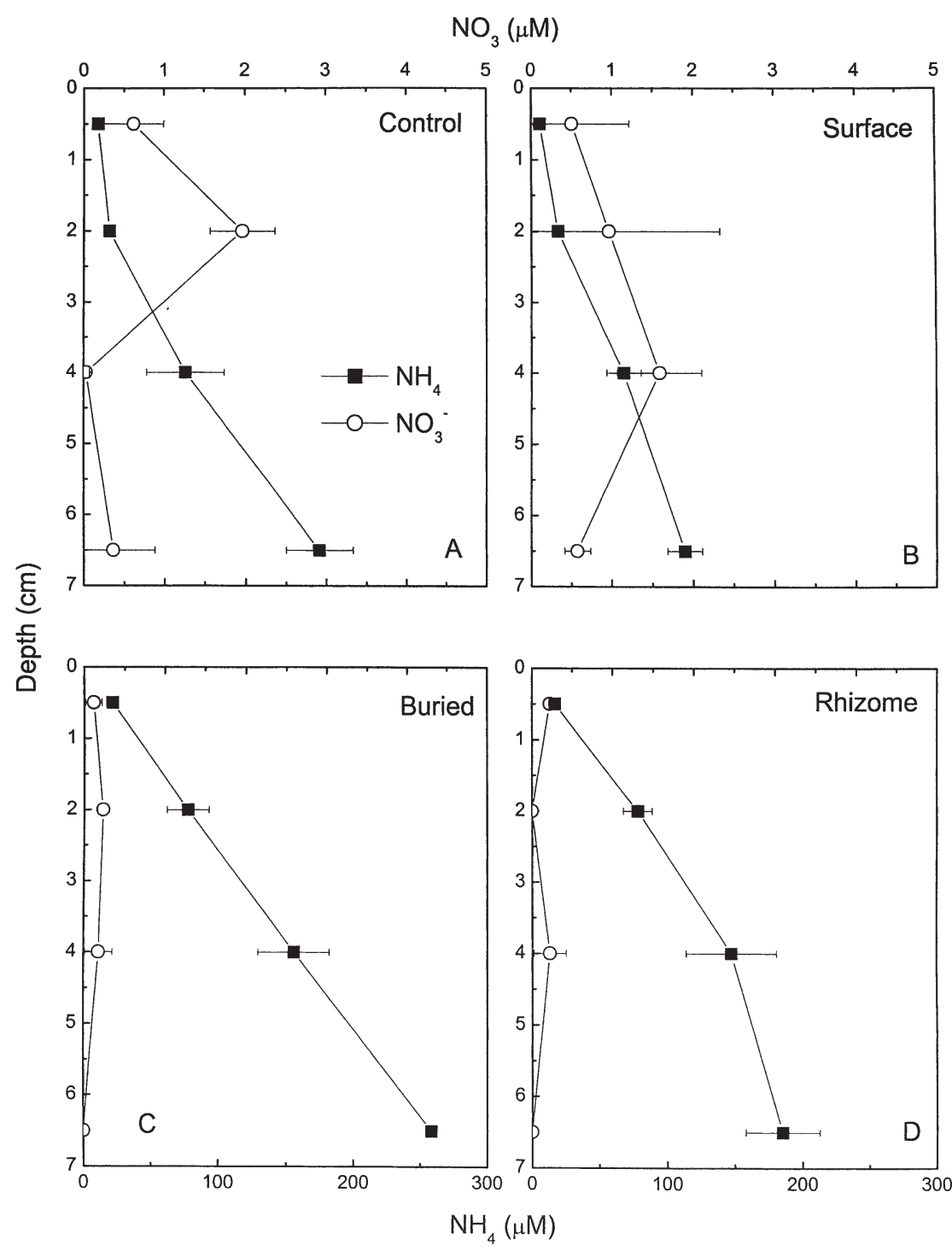

Fig. 8. Enhalus acoroides. Porewater profiles obtained after $43 \mathrm{~d}$ incubation with leaf and rhizome litter. (A) control; (B) leaf litter deposited on the surface; (C) leaf litter buried; and (D) rhizome litter buried in the sediments. Values are means $( \pm \mathrm{SEM}, \mathrm{n}=3)$

(1) The loss of carbon may have been overestimated because of difficulties with sampling-fragmented detritus; in particular, the seagrass detritus was highly degraded, whereas the mangrove leaves were recovered in one piece. (2) Carbonate precipitation or dissolution due to changes in $\mathrm{pH}$ during decomposition may have affected to $\mathrm{CO}_{2}$ concentrations; the $\mathrm{pH}$ did not, however, change with time or between treatments, suggesting that this effect was minor. (3) The $\mathrm{CO}_{2}$ production may have been underestimated due to the low frequency of $\mathrm{CO}_{2}$ flux measurements, especially during the initial decomposition period, in which major changes may take place within hours and days (Peder- sen et al. 1999). We found no excess loss of DOC during the initial decomposition phase, as has been measured in other seagrass decomposition experiments (Peduzzi \& Herndl 1991, Middelboe et al. 1998, Pedersen et al. 1999). This suggests that the release of DOM from Enhalus acoroides was low or that DOM was rapidly utilized by bacteria. Peduzzi \& Herndl (1991) found responses in the microbial community within $40 \mathrm{~h}$ after deposition of seagrass leaves in a litterbag experiment. The almost complete loss of organic carbon from the buried seagrass leaves in the field already after $1 \mathrm{wk}$, and in the laboratory after $43 \mathrm{~d}$, suggests that only a small fraction of the detritus was refractory and that longterm burial of seagrass leaf detritus was minor. This is consistent with the low organic carbon pools encountered in the seagrass sediments in the Bangrong mangrove (Holmer et al. 2001). The net gain of carbon in rhizome detritus indicates that the rhizomes were colonized by bacteria. Rapid colonization of seagrass detritus has been found (Harrison 1989, Peduzzi \& Herndl 1991), although the bacterial biomass is considered to contribute very little $(<5 \%)$ to the organic content of decomposing leaves (Rice \& Hanson 1984, Robertson 1988). In our experiment the increase in organic carbon was also small (3.9\%). The enhanced $\mathrm{CO}_{2}$ production despite the increase in organic carbon of the detritus (Fig. 9A) suggests that the decomposition of the indigenous organic carbon pool was enhanced by the amendment.

Export of DOC is considered an important link between mangroves and seagrass beds and oceans (Alongi et al. 1989, Wafar et al. 1997). Our results suggest that carbon mineralised in the sediments is exported in inorganic form, which is not likely to affect the microbial activity in the water column, and is in contrast to other mangroves (Steinke et al. 1993) and seagrass beds (Middelboe et al. 1998) where the microbial activity was stimulated by release of DOM from the sediments. Export of DOM from seagrass beds may, however, be substantial due to leaching of DOC, e.g. from decaying leave tips (Penhale \& Smith 1977). The high amount of mangrove detritus remaining $(\sim 40 \%)$ and the low rate of decomposition after the initial loss of labile components indicate that the burial of organic carbon was high and con- 

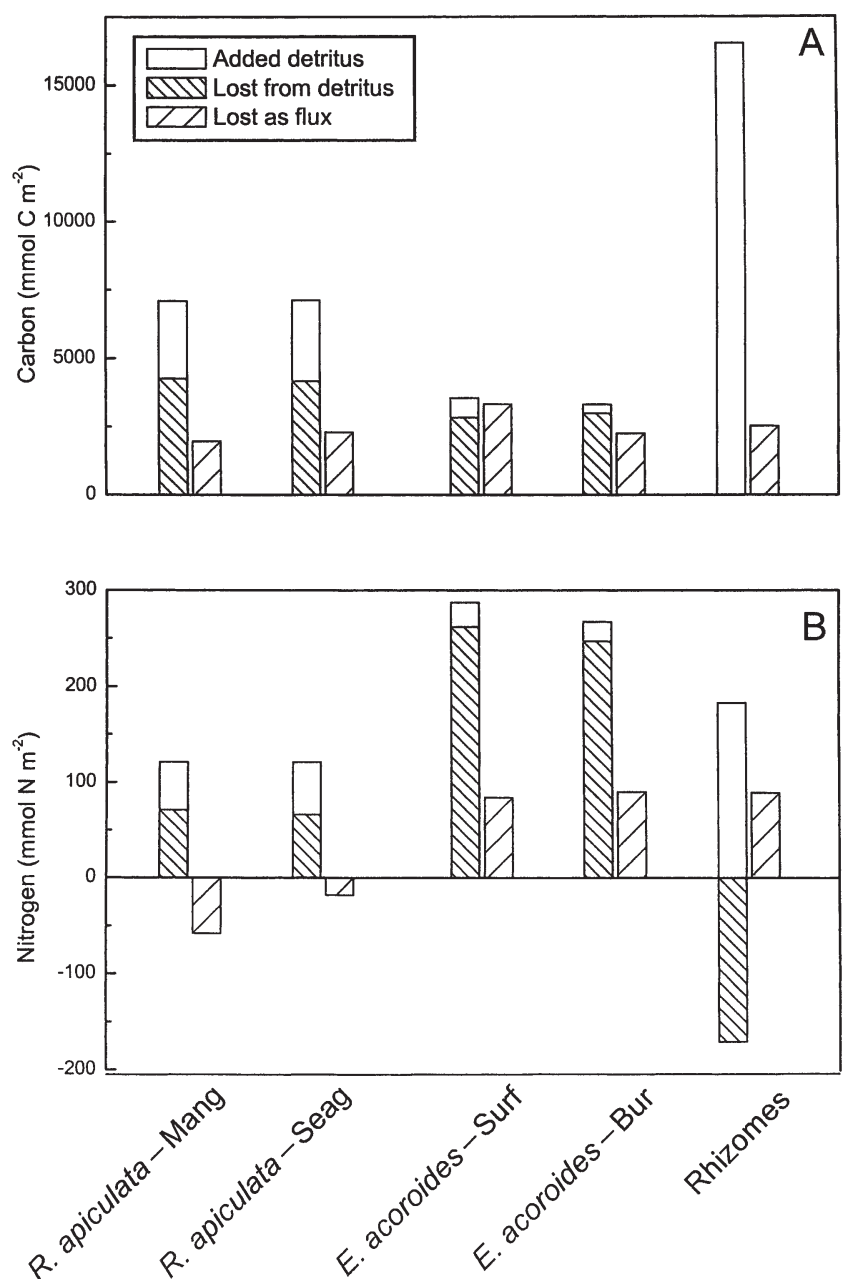

Fig. 9. Rhizophora apiculata and Enhalus acoroides. Added and lost carbon (A) and nitrogen (B) during $43 \mathrm{~d}$ of decomposition in the flux experiments. Lost as flux: time-integrated release or uptake in the amended cores subtracted from the changes in the control cores. There were no measurable changes in the particulate organic carbon and nitrogen concentrations in the sediments, and the porewater pools were $<1 \%$ of the fluxes and have not been included in the figure

tributed to the pool of refractory organic matter in mangrove sediments. The high burial of the mangrove leaves in the seagrass sediments, on the other hand, show that mangrove leaves were not a natural source in seagrass sediments, since the organic matter pools are low in these sediments and do not correspond to a high burial of mangrove detritus. Hemminga et al. (1994) found a high contribution of mangrove POM to organic matter in seagrass beds in the proximity of mangroves ( $<3 \mathrm{~km}$ away). The mangrove POM had gone through a phase of intense processing before sedimentation in the seagrass beds, and was composed of small fragments $(<1 \mathrm{~mm})$ with a low C:N ratio (8.5 to 11.2$)$. This processing most probably increased the decomposition potential compared to the leaves used in this experiment.

\section{Nitrogen dynamics during decomposition}

Porewater pools have been found to contribute relatively little to nitrogen budgets, while the fluxes across the sediment-water interface are of major importance (Kristensen et al. 1995, Pedersen et al. 1999). Similarly, the porewater pools were low in the examined sediments, but fluxes of inorganic nitrogen were also small. During decomposition of Zostera marina, Pedersen et al. (1999) found a high DON flux of a similar order of magnitude as the $\mathrm{NH}_{4}$ flux, but the lack of DOC release after the amendments in the present study indicates that the contribution of DON to the nitrogen cycling was minor in the mangrove and seagrass sediments examined here. Holmer et al. (2001) found a net uptake of DON in the Bangrong mangroves, which was attributed to nitrogen immobilisation during decomposition of nitrogen-poor detritus in the sediments.

The reduced efflux of nitrate after deposition of seagrass detritus suggests that nitrification was reduced or denitrification enhanced by the organic matter amendment. Nitrification in tropical mangrove and seagrass sediments is limited by $\mathrm{NH}_{4}$ due to low concentrations in the overlying water column and low rates of mineralisation in the sediments (Kristensen et al. 1998). The increase in $\mathrm{SOU}$ and $\mathrm{CO}_{2}$ production indicates that the mineralisation was enhanced by the addition of detritus, providing a source of $\mathrm{NH}_{4}$ for nitrification, but denitrification was most probably also enhanced. Denitrification is low in mangrove and seagrass sediments limited by low rates of nitrification and low nitrate and organic matter concentrations (Rivera-Monroy \& Twilley 1996, Kristensen et al. 1998). The large uptake of nitrate occurring immediately after the amendments in the seagrass sediments is similar to observations in coastal temperate sediments after sedimentation of a phytoplankton spring bloom (Jensen et al. 1990). Jensen et al. found that denitrification was stimulated by the organic matter supply, whereas nitrification was inhibited as the sediments turned anoxic, also in the surface layers. We did not measure oxygen penetration depth in these sediments, but the largest oxygen uptake was found in the sediments with leaves on the surface. High oxygen consumption in this layer may limit the penetration of oxygen into the sediments and inhibit nitrification, as suggested by a large loss of $\mathrm{NH}_{4}$. Jensen et al. found that an efflux of $\mathrm{NH}_{4}$ was due to a high production during mineralisation and lack of nitrification. Nitrification was probably re-established in the seagrass sediments, as indicated by the decrease in mineralisation after 20 to $40 \mathrm{~d}$, which was followed by uptake of ammonium and release of nitrate.

The amendment with mangrove detritus had a smaller effect on the inorganic nitrogen fluxes. Nitrate 
was only taken up in the seagrass sediments immediately after the amendments, and there was a small efflux the rest of the time, which was of minor importance in the overall nitrogen cycling $(<0.1 \%$ of ammonium flux). Ammonium was continuously taken up in the amended mangrove sediments, which was remarkable and in contrast to the findings of a net $\mathrm{NH}_{4}$ release after organic matter amendments (Pedersen et al. 1999). This suggests that there was a significant immobilisation of nitrogen during the degradation of the nitrogen-poor mangrove detritus. The larger loss of carbon compared to nitrogen in the mangrove leaves led to an overall decrease in the C:N ratios of the mangrove detritus. A decrease in the $\mathrm{C}: \mathrm{N}$ ratio of detritus is usually attributed to colonisation by bacteria (Steinke et al. 1993, Wafar et al. 1997), and Pedersen et al. (1999) found that bacteria incorporated nitrogen from the indigenous particulate organic nitrogen pool, whereas the detritus served as an energy source. The uptake of ammonium across the sediment-water interface suggests that the water column acted as a source of nitrogen, which is surprising as the nutrient concentrations generally are low in the overlying water in the Bangrong mangrove (Holmer et al. 2001). The higher $\mathrm{C}: \mathrm{N}$ ratios of the detritus and the lower weight loss in the mangrove sediments compared to the seagrass sediments suggests that the colonisation and activity of the bacteria was lower in the mangrove sediments. Low rates of mineralisation in mangrove sediments have been explained by high concentrations of tannins. Tannins are known to be enzymatic inhibitors and anti-microbial agents (Cundell et al. 1979), and studies have found a negative correlation between tannin content and bacterial population (Robertson 1988, Alongi et al. 1992, Steinke et al. 1993).

In contrast to the mangrove leaves, the $\mathrm{C}: \mathrm{N}$ ratio of Enhalus acoroides leaves increased during decomposition. This is consistent with the overall higher decomposition, especially of nitrogen, in the seagrass leaves (Fig. 9B). Compared to other seagrass species, E. acoroides leaves decompose fast, particularly in the field (Harrison 1989, Kenworthy et al. 1989, Opsahl \& Benner 1993). We found a loss of carbon and nitrogen of between 78 and $93 \%$ during $43 \mathrm{~d}$ of decomposition, whereas Pedersen et al. (1999) only observed the loss of about $27 \% \mathrm{C}$ and $11 \% \mathrm{~N}$ during $33 \mathrm{~d}$ of decomposition of Zostera marina leaves on a sediment surface. The C:N ratio was somewhat lower in E. acoroides than in Z. marina (12.4 vs 16.4), and the incubation temperature was twice as high $\left(28\right.$ vs $\left.14^{\circ} \mathrm{C}\right)$, which provides a potential for rapid decomposition. About 32 to $36 \%$ of the nitrogen lost from the detritus was released as ammonium across the sediment-water interface, whereas the rest remained unaccounted for, and was either released as $\mathrm{N}_{2}$ by denitrification or DON or retained in the sediments. The nitrogen released to the water column is available for uptake by seagrasses or phytoplankton and can be transported into the mangrove on ingoing tides or to the ocean on outgoing tides, depending on the residence time. This emphasises the importance of seagrass vegetation as a nutrient source in mangrove systems (de Boer 2000). Tropical seagrasses, however, have a large potential for uptake of nutrients by leaves and roots (Stapel \& Hemminga 1997), and the loss of nitrogen to the overlying water column may be less when the decomposition takes place inside seagrass beds and not (as in this experiment) when active plants are excluded from the sediments.

The decrease in C:N ratio of the Enhalus acoroides rhizomes and the increase in $\mathrm{N}$ concentration suggests that the rhizomes were colonised by bacteria. The net immobilisation of nitrogen during the decay of rhizomes demonstrates the importance of chemical composition in nutrient cycling. The carbon content was similar in leaves and rhizomes, whereas the nitrogen content of the rhizomes was only $10 \%$ of that of the leaves, and the nitrogen demand by the decomposing organisms was thus much higher for the rhizomes (Fenchel et al. 1998). Nitrogen for bacterial growth was not immobilised from the water column, as there was a net release of nitrogen from the sediments. The contribution of porewater pools to the budget was minor, but a rapid turnover from the particulate pools supported by the increased mineralisation may be an important pathway for supplying nitrogen. This also suggests that nutrient availability is an important controlling factor in the decomposition and burial of belowground biomass with high $\mathrm{C}: \mathrm{N}$ ratios in tropical seagrass meadows.

In summary, the amendment of tropical sediments with mangrove and seagrass detritus increased the carbon and nitrogen cycling within the sediments. There was only a minor burial of organic carbon from seagrass leaves in the sediments, whereas about $40 \%$ of the organic carbon in the mangrove leaves and all seagrass rhizome material were buried. The organic carbon was decomposed completely to $\mathrm{CO}_{2}$, with no apparent accumulation of DOC. The loss of organic nitrogen was high from the seagrass leaves and less from the mangrove leaves, whereas the rhizome material was enriched with nitrogen, which was attributed to bacterial colonization. The mineralised nitrogen was to a large extent retained in the sediments and an efflux of inorganic nitrogen was only found for the seagrass detritus. The early phase of degradation of mangrove leaves thus increases the availability of nutrients to the mangrove plants and detritus consumers in the sediments, whereas the nitrogen from the seagrass leaves is to a larger extent available to primary pro- 
ducers in the water column and for transportation between mangroves and the open ocean. The role of the more recalcitrant residual portion of mangrove leaves seems to be small due to slow rates of degradation. The same applies to the role of the residual pool of seagrass leaves, but this is due to the small size of the pool.

Acknowledgements. We are grateful to the staff of the Ecology Group at Phuket Marine Biological Center for assistance in the field and laboratory. A.B.O. and M.H. were supported by Danida, and M.H. was also supported by the Danish Natural Science Foundation grant nos. 9901749 and 1131.

\section{LITERATURE CITED}

Alongi DM (1996) The dynamics of benthic nutrient pools and fluxes in tropical mangrove forests. J Mar Res 54:123-148

Alongi DM, Boto KG, Tirendi F (1989) Effect of exported mangrove litter on bacterial productivity and dissolved organic fluxes in adjacent tropical nearshore sediments. Mar Ecol Prog Ser 56:133-144

Alongi DM, Boto KG, Robertson AI (1992) Tropical mangrove ecosystems. In: Robertson AI, Alongi DM (eds) Nitrogen and phosphorus cycles. American Geophysical Union, Washington, DC, p 251-292

Alongi DM, Christoffersen P, Tirendi F (1993) The influence of forest type on microbial-nutrient relationships in tropical mangrove sediments. J Exp Mar Biol Ecol 171:201-223

Armstrong FAJ, Stearns CR, Strickland JDH (1967) The measurement of upwelling and subsequent biological processes by means of the Technicon autoanalyser and associated equipment. Deep-Sea Res 14:381-389

Ashton EC, Hogarth PJ, Ormond R (1999) Breakdown of mangrove leaf litter in a managed mangrove forest in Peninsular Malaysia. Hydrobiologia 413:77-88

Benner R, Hodson RE (1985) Microbial degradation of the leachable and lignocellulosic components af leaves and wood from Rhizophora mangle in a tropical mangrove swamp. Mar Ecol Prog Ser 23:221-230

Boonruang P (1978) The degradation rates of mangrove leaves of Rhizophora apiculata (Bl.) and Avicennia marina (Forsk.) Vierh. At Phuket Island, Thailand. Res Bull Phuket Mar Biol Cent 26:1-7

Boto KG (1992) Nutrients and mangroves. In: Connell DW, Hawker DW (eds) Pollution in tropical aquatic systems. CRC Press, Boca Raton, FL, p 129-145

Boto KG, Wellington JT (1988) Seasonal variations in concentrations and fluxes of dissolved organic and inorganic materials in a tropical, tidally-dominated, mangrove waterway. Mar Ecol Prog Ser 50:151-160

Bower CE, Holm-Hansen T (1980) A salicylate-hypochlorite method for determining ammonia in seawater. Can J Fish Aquat Sci 37:794-798

Chale FMM (1993) Degradation of mangrove litter under aerobic conditions. Hydrobiologia 257:177-183

Cundell AM, Brown MS, Stanford R, Mitchell R (1979) Microbial degradation of Rhizophora mangle leaves immersed in the sea. Estuar Coast Shelf Sci 9:281-286

de Boer WF (2000) Biomass dynamics of seagrass and the role of mangrove and seagrass vegetation as different nutrient sources for an intertidal ecosystem. Aquat Bot 66(3): $225-239$
Dick TM, Osunkoya OO (2000) Influence of tidal restriction floodgates on decomposition of mangrove litter. Aquat Bot 68:273-280

Enriquez S, Duarte CM, Sand-Jensen K (1993) Patterns in decomposition rates among photosynthetic organisms: the importance of detritus C:N:P content. Oecologia 94: $457-471$

Eong OJ (1993) Mangroves-a carbon source and sink. Chemosphere 27:1097-1107

Erftemeijer PLA, Middelburg J (1995) Mass balance constraints on nutrient cycling in tropical seagrass beds. Aquat Bot 50:21-36

Fenchel T, King GM, Blackburn TH (1998) Bacterial biogeochemistry: the ecophysiology of mineral cycling. Academic Press, London

Hall POJ, Aller RC (1992) Rapid, small-volume, flow injection analysis for $\Sigma \mathrm{CO}_{2}$ and $\mathrm{NH}_{4}{ }^{+}$in marine and fresh water. Limnol Oceanogr 37:1113-1119

Harrison PG (1989) Detritial processing in seagrass systems: a review of factors affecting decay rates, mineralization and detritivory. Aquat Bot 23:263-288

Hemminga MA, Nieuwenhuize J (1991) Transport, decomposition, and in situ decay of seagrass in a tropical mudflat area (Banc d'Arguin, Mauritania). Neth J Sea Res 27: 183-190

Hemminga MA, Harrison PG, van Lent F (1991) The balance of nutrient losses and gains in seagrass meadows. Mar Ecol Prog Ser 71:85-96

Hemminga MA, Slim FJ, Kazungu J, Ganssen GM, Nieuwenhuize J, Kruyt NM (1994) Carbon outwelling from a mangrove forest with adjacent seagrass beds and coral-reefs (Gazi Bay, Kenya). Mar Ecol Prog Ser 106:291-301

Holmer M, Andersen FØ, Holmboe N, Kristensen E, Thongtham N (1999) Transformation and exchange processes in the Bang Rong mangrove forest-seagrass bed system, Thailand: seasonal variations in benthic primary production and nutrient dynamics. Aquat Microb Ecol 20: 203-212

Holmer M, Andersen FØ, Holmboe N, Kristensen E, Thongtham N (2002) Spatial and temporal variability in benthic processes along a mangrove-seagrass transect near the Bangrong mangrove, Thailand. Wetlands Manag (in press)

Jensen MH, Lomstein E, Sørensen J (1990) Benthic $\mathrm{NH}_{4}{ }^{+}$and $\mathrm{NO}_{3}{ }^{-}$flux following sedimentation of a spring phytoplankton bloom in Aarhus Bight, Denmark. Mar Ecol Prog Ser 61:87-96

Kenworthy WJ, Thayer GW (1984) Production and decomposition of the roots and rhizomes of seagrass, Zostera marina and Thalassia testudinum, in temperate and subtropical marine ecosystems. Bull Mar Sci 35:364-379

Kenworthy WJ, Currin CA, Fonseca MS, Smith G (1989) Production, decomposition, and heterotrophic utilization of the seagrass Halophila decipiens in a submarine canyon. Mar Ecol Prog Ser 51:277-290

Kristensen E, Andersen FØ (1987) Determination of organic carbon in marine sediments: a comparison of two CHNanalyzer methods. J Exp Mar Biol Ecol 109:15-23

Kristensen E, Holmer M, Banta GT, Jensen MH, Hansen K (1995) Carbon, nitrogen and sulfur cycling in sediments of the Ao Nam Bor mangrove forest, Phuket, Thailand: a review. Phuket Mar Biol Cent Res Bull 60:37-64

Kristensen E, Jensen MH, Banta GT, Holmer M, King GM (1998) Transformation and transport of inorganic nitrogen in sediments of a southeast Asian mangrove forest. Aquat Microb Ecol 15:165-175

Kristensen E, Andersen FØ, Holmboe N, Holmer M (2000) 
Carbon and nitrogen mineralization in sediments of the Bangrong mangrove area, Phuket, Thailand. Aquat Microb Ecol 22:199-213

Lee SY (1995) Mangrove outwelling: a review. Hydrobiologia 295:203-212

Middelboe M, Kroer N, Jørgensen NOG, Pakulski D (1998) Influence of sediment on pelagic carbon and nitrogen turnover in a shallow Danish estuary. Aquat Microb Ecol 14:81-90

Moeslund L, Thamdrup B, Jørgensen BB (1994) Sulfur and iron cycling in a coastal sediment: radiotracer studies and seasonal dynamics. Biogeochemistry 27:129-152

Moran MA, Hodson RE (1989) Bacterial secondary production on vascular plant detritus: relationships to detritus composition and degradation rate. Appl Environ Microbiol 55: $2178-2189$

Morell JM, Corredor JE (1993) Sediment nitrogen trapping in a mangrove lagoon. Estuar Coast Shelf Sci 37:203-212

Newell SY, Fell JW, Statzell-Tallman A, Miller C, Cefalu R (1984) Carbon and nitrogen dynamics in decomposing leaves of three coastal marine vascular plants of the subtropics. Aquat Bot 19:183-192

Opsahl S, Benner R (1993) Decomposition of senescent blades of the seagrass Halodule wrightii in a subtropical lagoon. Mar Ecol Prog Ser 94:191-205

Pedersen AGU, Berntsen J, Lomstein BAA (1999) The effect of eelgrass decomposition on sediment carbon and nitrogen cycling: a controlled laboratory experiment. Limnol Oceanogr 44:1978-1992

Peduzzi P, Herndl GJ (1991) Decomposition and significance of seagrass leaf litter (Cymodocea nodosa) for microbial food web in coastal waters (Gulf of Trieste, northern Adriatic Sea). Mar Ecol Prog Ser 71:163-174

Penhale PA, Smith WO (1977) Excretion of dissolved organic carbon by eelgrass (Zostera marina) and its epiphytes. Limnol Oceanogr 22:400-407

Poovachiranon S, Chansang H (1994) Community structure

Editorial responsibility: Otto Kinne (Editor),

Oldendorf/Luhe, Germany and biomass of seagrass beds in the Andaman Sea. I. Mangrove-associated seagrass beds. Phuket Mar Biol Ctr Res Bull Mar Sci 59:53-64

Rice DL, Hanson RB (1984) A kinetic model for detritus nitrogen: role of the associated bacteria in nitrogen accumulation. Bull Mar Sci 35:326-340

Rivera-Monroy VH, Twilley RR (1996) The relative role of denitrification and immobilization in the fate of inorganic mangrove sediments (Terminos Lagoon, Mexico). Limnol Oceanogr 41:284-296

Rivera-Monroy VH, Day JW, Twilley RR, Vera-Herrera F, Coronado-Molina C (1995) Flux of nitrogen and sediment in a fringe mangrove forest in Terminos Lagoon, Mexico. Estuar Coast Shelf Sci 40:139-160

Robertson AI (1988) Decomposition of mangrove leaf litter in tropical Australia. J Exp.Mar Biol Ecol 116:235-247

Sharp JH (1997) Marine dissolved organic carbon: are the older values correct? Mar Chem 56:265-277

Slim FJ, Hemminga MA, Cochert De La Moriniere E, van Velde G (1996) Tidal exchange of macrolitter between a mangrove forest and adjacent seagrass beds (Gazi Bay, Kenya). Neth J Aquat Ecol 30:119-128

Stapel J, Hemminga MA (1997) Nutrient resorption from seagrass leaves. Mar Biol 128:197-206

Steinke TD, Holland AJ, Singh Y (1993) Leaching losses during decomposition of mangrove leaf litter. S Afr J Bot 59: $21-25$

Subramaniyan PMJ, Jeyaseelan P, Krishanmoorthy K (1984) The nature of biodegradation of vegetation in a mangrove ecosystem. Chem Ecol 2:47-68

Wafar S, Untawale AG, Wafar M (1997) Litter fall and energy flux in a mangrove ecosystem. Estuar Coast Shelf Sci 44: $111-124$

Woodroffe CD (1985) Studies of a mangrove basin, Tuff Carter, New Zealand. III. The flux of organic and inorganic particulate matter. Estuar Coast Shelf Sci 20: $447-462$

Submitted: April 11, 2001; Accepted: August 14, 2001

Proofs received from author(s): March 6, 2002 